\title{
Imam Suprayogo's Perspective on Contextualization in Education
}

\author{
Maidar Darwis \\ Tapaktuan State Islamic Collage \\ Maidar1977@gmail.com
}

\begin{abstract}
This research deals with Imam Suprayogo's Thought Contextualization in the World of Education. Contextualization is an effort to put things in context. The concept of science integration Imam Suprayogo has been Indonesian. The curriculum is an educational design that has a fairly central position in all educational activities and as a determinant of the implementation process and educational outcomes. The research method used in this study is descriptive analysis method or literature review. The finding shows that contextualization is an effort to put things in context. The concept of science integration Imam Suprayogo has been Indonesian. From several advantages of the integration concept initiated by him, many other universities tried to contextualize his thoughts in their respective campuses. And now, education programs have also begun to be discussed and implemented in several other Islamic Universities in Indonesia, such as UIN Raniry, Sunan Kalijaga UIN, Syarif Hidayatullah State Islamic University and several other Islamic Universities.
\end{abstract}

Keywords : Education; Contextualization; Imam Suprayogo's Perspective.

\section{Introduction}

Later we see the government's attention to the role and progress of Islamic education in Indonesia so much, one of which is by encouraging Internationalization of Indonesian Islamic education by making Indonesia the center of world Islamic studies. And that is pursued through Islamic educational institutions that meet the qualifications for that. This is not an exaggeration, considering that Indonesia is a Muslim majority in the world And also as the third largest democracy in the world. Therefore, scientific integration in the field of education, especially Islamic education is something that is expected. Because, as is known, since the beginning of independence, the existence of Islamic educational institutions has always been at the periphery. Thank God, since Mukti Ali served as Minister of Religion of the Republic of Indonesia, has given birth to the entry points for the modernization of madrasas and pesantren through the SKB of the Three Ministers (Minister of Religion, Minister of P \& K, and Minister of Home Affairs) No. 6 of 1975. Where the Three Ministerial Decree is one of the most important milestones in the integration of Islamic education into the mainstream of national education. Furthermore, this policy is essentially the first step for the "reintegration" of religious sciences and general sciences in Islamic educational institutions.

Based on the historical facts above, then some Islamic intellectual leaders then strive to uncover the barrier to Islamic education, namely by bringing back the integrated term of science. One of the characters who wants to be studied in this paper is Prof. DR. H. Imam Suprayogo, who tried to uncover the veil of the rise of Islam by offering an approach called the "Tree of Knowledge of Maliki UIN Malang" approach with the concept of tarbiyah ūlūl albābb as an alternative to the development of Islamic educational institutions in addressing the challenges of globalization and deterioration in current and future national education.

Imam Suprayogo has revealed leadership qualities during several leading periods at Maliki UIN Malang. Therefore, it is necessary to study Imam Suprayogo's thoughts, concepts, leadership and managerial so that they can become a reference for the practice of PTAI leaders and PTAI campus residents in making changes. Through the tree science approach 
and the tarbiyah ūlūl albābb concept, Imam Suprayogo explained concretely about the concept of integrated science.

Imam Suprayogo who is one of the leaders who have broken down the Islamic community, through the tree-of-science approach that he offers has brought educational institutions that he leads to the front guard and is respected and has a strategic position and calculated both in the Ministry of Religion and in the ranks Ministry of Education and Culture, because it has been able to produce output that is in accordance with the orientation of the social dynamics of the community. This can be evidenced by the student graduates who have sufficient scientific capacity to respond to challenges in the global era which are then personified as scholars who are professional intellectuals and professional intellectuals who are scholars.

\section{History of the Life of Imam Suprayogo}

Imam Suprayogo is one of the influential figures in Java. Especially in the world of Islamic education. Its work is quite phenomenal. He can be called mujādid, how not, in his hands the Malang Maliki UIN which used to be small has now become a magnificent and respected building and gained recognition from various circles, because of its extraordinary development both in terms of scientific development concepts, institutions, facilities and infrastructure, academic , student affairs, and management (management) aspects, which were achieved only in a short time for the size of a college.

He aggressively and deftly utilizes and optimizes internal and external sources, so that the Maliki UIN Malang can be trusted by foreign students from 20 countries who study at universities that have assets of trillions of rupiah. As well as the campus with a magnificent physical performance and a modern blend of Middle Eastern-style architecture ${ }^{1}$, aspiring to be the center of excellence and center of Islamic civilization while implementing Islamic teachings as a blessing for the universe. Prof Imam conducts reforms in the field of education in ways that unusual. Unusual methods mean, relying on the support of external funds without having to beg to the government.

At a glance the curriculum vitae of the winner of the IFI (Islāmic Fair of Indonesia) Award in the Education Figures category and the recipient of the award from the Manado Post is indeed not a special figure, but he will be interesting to know both in terms of leadership, spark of thought and action give now. Imam Suprayogo is a hitman, he has talent as "leverage" a lever. In fact, Dr. Muhammad Zein Head of Subdirektorat Academic Development, DIKTIS, Directorate General of Islamic Education, Ministry of Religion in an article dubbed him a "True Entrepreneur". According to Mr. Dr (HC) Ir. Ciputra, there are three characteristics of innovative entrepreneurs, namely: (a) opportunity creators (opportunity creators), dare to think out of the box; (b) innovator (innovator); (c) calculated risk taker (measured risk taker). Entrepreneurs are those who have creativity and are able to create new innovations. And he said that Prof. The priest has the three characters in question. Meanwhile, Prof. Syafii Maarif praised Imam Suprayogo as a leader who has strong imagination and big dreams.

\footnotetext{
${ }^{1}$ Tyas Haryadi, Malang Maliki UIN Kampukus; http://tyasharyadi.blogspot.co.id/2011/10/uin-maliki-malangkampusku.html, adapted and quoted on Tuesday, November 22, 2016.
} 
Meaningfully, the son of the KH. Hasan Muchroji and $\mathrm{Hj}$. Mariah named Imam Suprayogo, which in Javanese means a good priest. With that name, as the meaning contained in it, it is hoped that one day he can become a good leader for the family, the people of the nation and his religion.

He was born in the village of Gemoharjo Watulimo a village in the area of Trenggalek on January 02, 1951. Gemoharjo is a mountain village located $32 \mathrm{~km}$ south of the city of Trenggalek with approximately $7 \mathrm{~km}$ from the southern coast of the island of Java. As a mountainous area and many hills in this village, many work as farmers. When Prof. Priests are still children of public transportation in this region arguably can still be counted on the fingers, so everywhere people travel on foot without bare feet.

He grew up in the tradition and devout NU family. His father was a local NU administrator and his mother was a Muslimat administrator. Both are people who both like to organize and preach. That is why, both of them want him to grow to be a da'i. The reason is that preaching can be done easily. By preaching, then someone will be able to easily take heart and position in his community. But in reality, said the Doctor of Sociology from Unair Surabaya, inviting to goodness is not an easy thing. Especially for him, who at that time actually took his education level from elementary to high school. Although he was handed over as the Head of MI NU managed by his father, he still felt how difficult it was to become the da'i. From there he became aware, that to preach it was necessary to stay at the pesantren to deepen the religious sciences.

Based on the narrative of several families as the writer quoted in the Fatkurrohman thesis, that Prof. The priest is a strong-willed person, not easy to give up on difficulties and unruly. In the event that his education is classified as mediocre, there is no special achievement that he got during school. Only one of his advantages, which was admired by his friends, was the problem of counting which always excelled. On the other hand, lessons related to memorization always end. After graduating from elementary school in 1958, Prof. The priest then proceeded to the SMPN in the city of Kawadenan Kampak and continued to SMAN Trenggalek. He prefers public schools with the aim of having more space to move. Unlike the older siblings who prefer religious schools.

\section{Research Method}

The approach used in this study is to use a literature review method or literature review, namely: A description or description of the literature relevant to a particular field or topic. He provides a review of what has been discussed or discussed by the researcher or author, supporting theories and hypotheses, research problems that are proposed or stated, methods and methodologies that are appropriate. Such research reports will contain excerpts of data and data processing to illustrate presentation of the report.

With library research, a study can use descriptive analytical methods, namely data obtained in the form of words, images and behavior that are not expressed in the form of numbers or statistics, but remain in a qualitative form by giving a description of the situation under study in the form of narrative descriptions. So, in detail by using a qualitative descriptive method more describing what it is about a variable, symptom or condition.

Data collection technique is an important process that must be carried out by researchers to obtain a research source so that they can obtain the results expected by researchers. According to Sugiono: "There are two things that affect the quality of research data, namely 
the quality of research instrument research and data collection quality. The quality of the instrument relates to the methods used to collect data. "Meanwhile, Sumadi Suryabrata stated that" The quality of data is determined by the quality of data retrieval tools or measuring devices. If the data retrieval tool is quite reliable and valid, then the data will also be quite reliable and valid. "

There are several ways to collect data needed in a study, both qualitative, quantitative and content analysis. According to Arikunto "the technique of data collection can be done using tests, interviews, questionnaires, observation, documentation and combination." Thus, in this study the authors conducted data collection techniques by collecting data sources relevant to Imam Suprayogo's thoughts on scientific integration, namely:

\section{a. Primary Data Source}

Primary data source is "data that is directly collected by researchers (or their officers) from their first source". The primary sources in this study are a number of books by Imam Supragoyo, for example the book Building Integration of Science and Religion, Reviving the Soul of Science, Al-Qur'an Education Paradigm, Superior Islamic University, Reformulation of Islamic Education Vision, Changing Islamic Higher Education: Reflections on IAIN / Change STAIN Becomes UIN, and a number of articles that entered the MURI Record that wrote Articles on the Oldest 3-Year Website without Pause. Such as the Implementation of the Concept of Integration of Science and Religion, Strengthening the Academic Culture of Higher Education, Boarding Higher Education, Capturing Hope for Islamic Universities, Understanding the Tree Roots of UIN Malang Sciences, Leading and Managing Islamic Educational Institutions, Problems of Islamic Higher Education Development, Strategic Steps to Advancing and Raising Campus, Strategic Position of Lecturers in Higher Education, Becoming Widely Known Scientists, When Knowledge Is Not Written, Between Alumni of Higher Education Islamic Boarding Schools and Alumni, Dissertation and Leadership, When Religion Is Made into Debate and a number of other relevant articles.

b. Secondary Data Sources

According to Sugiono, secondary data is data that does not directly provide data to researchers, for example research must go through other people or search through documents. This data is obtained using literature studies conducted on many books.

\section{Discussion}

The curriculum is an educational design that has a fairly central position in all educational activities and as a determinant of the implementation process and educational outcomes. An education curriculum should contain several key elements such as goals, subject content, teaching methods and research methods. All of them must refer to a source of strength which is the basis of its formation. This source of strength is said to be the principles forming the education curriculum.

UIN and IAIN whose curriculum is a reference for high schools and institutes spread throughout Indonesia still have not been able to present a curriculum that contains elements that shape the Islamic outlook, in which metaphysics and Islamic epistemology are contextualized and set forth in compulsory subjects for all faculties so that it becomes the principle for all disciplines. The division of the faculty of usuluddin, sharia, tarbiyah, adab, 
and da'wah still requires further development so that it reflects the meaning of al-jami'ah or kulliyah which means universal.

The curriculum needs to be oriented in order to produce scholars who not only have authority in their fields, but also authority in the sciences of Islam and the general sciences. For this reason, it is now beginning to seek the development of Islamic education that leads to the demands of needs in the present context. One of them is by conducting curriculum reconstruction through the concept of scientific integration program as initiated and implemented by Imam Suprayogo at the Maliki UIN Malang based on tarbiyah ulul albab, which is explained through matafora a tree.

The concept of scientific integration initiated by Imam Suprayogo has experienced extraordinary applications. Imam Suprayogo with his concept has led UIN Maliki Malang to be in the first grade for the most successful campus category in implementing the concept of integration of science and religion which is explained through a tree metaphor. Departing from this fact, now related to how the concept of his thinking, implementation strategy, much learned, was adopted by various other universities, which tried to contextualize his thoughts.

Contextualization is an effort to place something in its context, so that it fits in with its sociohistorical environment. When the environment changes, in this case of course adjustments must be made to the environment and new era. Such an effort is called contextualization. Contextualization of the concept of integration in an educational institution as conceived and implemented by Imam Suprayogo is a necessity, in order to remain in accordance with the conditions and times so that it still has a vital role in answering the actual problems that arise in today's globalization era.

One form of applying the context of contextualization is that the curriculum of educational institutions intentionally, well, and regularly is designed to always be in accordance with the context. It is the duty of every educational institution to design an educational curriculum so that it remains relevant and can maximize all existing potential in accordance with local wisdom.

Imam Suprayogo has carried out curriculum reconstruction at the educational institutions he leads. He dared to make a big change for the sake of goodness and benefit even with high risk because it was out of the context of the policy set by the central government, namely by reconstructing curriculum development in Islamic Higher Education (UIN Maliki Malang) which was implemented in an integrated manner between general science and religious making Islamic teachings and values as a guide and source of consultation for the development of various general subjects by inserting Islamic teachings and values into the field of general study, because according to him the Islamic education curriculum must be built from the formulation of understanding of divine revelation and reality empirical which contains it (kauniyah).

The Islamic education curriculum is directed at how to prepare graduates who have a complete character and soul. In addition, they also have the skills and expertise that are needed for life and life. In today's Islamic education curriculum is adaptively oriented and truly real to provide resistance to moral decadence, spiritual decline and low quality of knowledge and skills.

In accordance with the Indonesian context, Islamic education is strongly influenced by culture, ideology and the strong ways of religion. Therefore, a formatted Islamic education curriculum that is capable of touching something substantial such as cultural values, ideology and the level of diversity found in this nation. Therefore, the contextualization of the Islamic 
education curriculum is expected to contribute positively to the behavior of students, especially the formation of character, awareness of religious spirituality, and intellectual and professional maturity. Therefore, many ideas emerged about the need to reinterpret and reorient, including making a paradigm shift from the current practice of education.

The paradigm changes include relating to education which must be carried out with an academic approach, not bureaucratic, education must be oriented to print mentality learners seeking knowledge, not waiting for knowledge, students must be educated to be active, not passive, education must be oriented towards students ( student-oriented), not an educator or state (teacher and state-oriented), humans must be seen the anthropocentrically theocentric, not only anthropocentric, management of education should not be centralized, but must be decentralized, religious education should not be delivered dogmatically, and education must be inclusive, integralistic and holistic.

The Islamic education curriculum must be built integrally and synergistically between the dimensions of revelation, the dimensions of the depth and social dimension of humanity, which within the Maliki UIN Malang as described earlier in the process of implementation is known as the slogan "tarbiyah ūlūl albāb" which has various approaches with the formulation that is owned, namely, dzikir, fikr, and charity șaleh. Through the integration of these dimensions, Islamic education curriculum is intended to solve problems in the world of education (Islam).

Philosophically, the level of progress of human life is largely determined by educational engineering based on superior, advanced and integral curriculum. Islamic Education curriculum must be a powerful force to deal with a more crucial life discourse. When globalization becomes part of human life, new problems arise with a variety of forms. Such challenges must be responded appreciatively so that the Islamic education curriculum is not said to be out of date. Reflection of thought and formulation of the Islamic education curriculum must be up to date.

In the historical eye, we can see the past as a lesson (ibrah), but don't forget to pay attention to the present and the future as capital for improvisation and fundamental change. So that Islamic education does not fall into the pit of destruction, the curriculum improvisation process must be continuously adapted and contextualized. Planning, organizing, implementing and evaluating Islamic education curricula should never stop, if you really want to maintain trust (trust) and uphold the progress of society.

\section{Balance of Intellectuality and Spirituality}

Education is not only emphasized on cognitive aspects, which are only relying on the intelligence of the left brain, but need to be balanced with other aspects, such as affective and psychomotor. All of which are related education, not compartmentalized, integrated and holistic. Education is actually holistic in that it places emphasis on three main domains, namely cognitive, affective and psychomotor. Both intellectuality and spirituality must work in synergy (balance).

Spirituality for a person is not to be an ascetic expert, sitting pensively and quietly enjoying the beauty of spirituality. Whereas intellectuality for a person himself is not as a scientist or politician who constantly pursues wealth and the world. To balance intellect and spirituality, one must think of pursuing wealth or the world as if he were living forever and perfecting his worship as if he were dead tomorrow. In this way, a balance will be established which will give birth to a responsible, honest and wise person. 
Students should not only pursue science alone to achieve their goals. They also have to balance the remembrance of God so that it does not deviate in the direction that leads to the valley of evil. So that it will become immoral scholars, and will become a disease for the nation and state. This of course also cannot be done spontaneously, for this reason it needs to be planted and familiarized as early as possible through the process of habituation. Because according to Imam Suprayogo, one of the essence of education is the process of habituation and imitation. And finally it will become a person who is accustomed to making a balance between these two aspects. In the scope of Maliki UIN Malang, this balance must be practiced in a real way by all students through several activities that reflect these two aspects.

The intellectual aspect was developed by building a strong scientific tradition by conducting research. While the aspect of spirituality is formed through a process of habituation, such as getting used to congregational prayer, khoṭmul al-Qur'ān, sunnah fasting and increasing recitation of remembrance. Which is practiced istiqamah. Although the direction of each of these efforts is different, the application must be an integrated effort so as to be able to realize the complete existence of students.

In the daily practice of UIN Maliki Malang students are directed to have self-awareness by heeding the values of spirituality to always be used as a basis for moral considerations in carrying out an act and intellectuality to obtain analytical calculations in considering the negative positive consequences of their actions. If this is fulfilled, surely the life of the nation and state of Indonesia will be respected by other nations in competition in the global era. As the nation's most valuable asset, students are the next generation who are encouraged to bring the future of the life of the nation and state. Destroyed and the glory of this country depends on young people, especially students as educated elite groups.

For this reason a balance between intellectuality and spirituality is needed in the lives of students so that later they can distinguish between good and bad so that they can contribute the best results to their religion, nation and country. The expected results of education are human beings who have quality abilities, high quality of reasoning so that they can master science, can compete in exploring the advancement of science and technology in the present and in the future.

From the development of these aspects of quality, in the end a complete quality of human beings is created which is based on the quality of faith and piety (IMTAQ) which is the most basic target of education. The full quality of human beings based on the quality of the IMTAQ is a development of quality that is harmonious between several human aspects as described above.

\section{The advantages and disadvantages of the concept of scientific integration of Imam Suprayogo}

Speaking of advantages for the measure of achievement achieved by Imam Suprayogo certainly cannot be seen as one eye. Such a measure of achievement is a remarkable achievement. Because the history of the struggle is very long and there are many challenges in achieving it, so only certain people have succeeded in achieving the intended mission. Namely those who are always consistent and istiqamah with their mission in the midst of pressure and challenges which in turn their successes and great achievements are then able to attract the attention of various parties and be recognized so that it becomes an advantage for their fighters. 
As with Imam Suprayogo with the concept of scientific integration which has various sides of excellence that become more value. However, whose name is the result of human formulation with imperfect nature certainly has drawbacks. However, this lack is not an excuse for us to justify and deny the results of his thoughts and hard work which have proven to have succeeded in bringing Islamic University to become a quality scientific, da'wah and Islamic education institution through the concept of scientific integration that he offers. The shortcomings referred to are only related to technical issues when the concept is tested or implemented on different objects (other universities) ${ }^{2}$, or at a certain level. Like for example when we try to implement it at the material level during the learning process.

The science integration program requires the change of STAIN and IAIN status to become UIN, which then requires the opening of faculties and departments categorized as general majors, indeed it has added new nuances and thoughts among the UIN academic community. Views of natural phenomena and thoughts about them that have not been widely known in the tradition of religious sciences began to be often conveyed by exact lecturers (public faculties), both in discussions and lectures.

However, as noted by $\mathrm{Saleh}^{3}$, the opening of the general department at UIN which was then followed by a recruitment program for its lecturers, most of which were also taken from general PTN graduates, was apparently not without problems. Methodologically and scientifically, they are different from the patterns and systems of thinking in the religious sciences that have been developed in UIN. This can lead to gaps and conflicts between religious and public lecturers. At the very least, it can cause confusion among students.

It can be imagined, if a lecturer states that the source of knowledge is the senses and the method is observation, while the other states the source of knowledge is intuition and the method is cleansing the heart (kasyf). Or a lecturer stated that his scientific discipline was purely empirical without being related to religious dogma, while other lecturers stated that none of the disciplines were separated from the observation of the sacred text. That fact really happened almost in all UIN.

To overcome this problem, according to Imam Suprayogo (Reconstruction of the Islamic Paradigm of Islamic Higher Education), the leaders of UIN have actually taken steps to resolve what is known as the "science integration program". In the concept of integration, the position of religious and general science is described in what is called the "tree of knowledge". In this tree of science, the Qur'an and al-Hadith are positioned as the result of experiments and logical reasoning, both of which are sources of scientific inspiration, so there is no difference between religious and public sciences because each is based on the same source.

As mentioned and acknowledged by him that the discourse of integrating science when tested by other Islamic universities did experience many obstacles and complaints by the higher education leaders themselves. Indeed, he also acknowledges that the process of integrating knowledge is indeed not easy, but requires a very long time and a long and very tiring process. He said progress was a product of a long process ${ }^{4}$. In addition, according to him, the key to success will be different between educational institutions in different places.

\footnotetext{
${ }^{2}$ Imam Suprayogo, Implementasi Konsep Integrasi Ilmu dan Agama; adapted and quoted on Sunday, November 27, 2016.

3 Soleh, Integrasi Agama-Umum

${ }^{4}$ Imam Suprayogo, Keberhasilan Membangun
} 
The same thing was admitted by Amin Abdullah, which he was the initiator of the integration of religious sciences and general sciences which he applied in Sunan Kalijaga UIN Jogjakarta.

He (Amīn "Abdullāh) said that the integration-interconnection paradigm which has now become the scientific development paradigm of Sunan Kalijaga UIN was not just born, but followed a long process that involved a lot of discussion with experts from both domestic and overseas $^{5}$. However, Prof. Imam said that the discourse of integrating general and religious sciences should not be dimmed but must continue to be improved. Therefore, to minimize various shortcomings related to the concept of scientific integration, further research is needed in order to find and reveal the latest concepts to perfect and fix the deficiencies in question.

It should be noted, to achieve goals is not easy, various internal and external challenges will occur. Therefore, it requires strong, courageous, and visionary leaders and even a little authoritarian in the management of the institutions that he manages in order to erase the old paradigm (dichotomic view) which has been considered correct and established towards new thinking (the integration of science) into the mainstream system education.

Here are some advantages of Imam Suprayogo's concept of scientific integration.

a. Able to produce graduates who have two advantages, namely scholars who are intellectuals and intellectuals who are scholars;

b. Through the concept of scientific integration, making UIN Maliki Malang becomes a reference for foreign students;

c. As the only Islamic tertiary institution that applies the concept of education in person

d. An Islamic College that has a strong character that is a blend of religious academic culture with academic culture as an institution of scientific development with a research culture (research).

\section{Conclusion}

Contextualization is an effort to put things in context. The concept of science integration Imam Suprayogo has been Indonesian. From several advantages of the integration concept initiated by him, many other universities tried to contextualize his thoughts in their respective campuses. And now, education programs have also begun to be discussed and implemented in several other Islamic Universities in Indonesia, such as UIN Raniry, Sunan Kalijaga UIN, Syarif Hidayatullah State Islamic University and several other Islamic Universities.

\section{References}

Abdullah, Amin. Islamic Studies di Perguruan Tinggi; Pendekatan Intergatif-Interkonektif. Yogyakarta: Pustaka Pelajar, 2006.

(__ Integrasi Sains-Islam: Mempertemukan Epistemologi Islam dan Sains. Yogyakarta: Pilar Religia, 2004.

Abidin Bagir, Zainal. Integrasi Ilmu dan Agama: Interpretasi dan Aksi. Bandung: Mizan, 2005.

Abdussalam, Suroso. Sistem Pendidikan Islam. Bekasi: Succes Publishing, 2011.

Arikunto, Suharsimi. Prosedur penelitian Suatu pendekatan Praktek. Jakarta: Rineka Cipta, 2010.

\footnotetext{
${ }^{5}$ Siswanto, Perspektif Amin Abdullah about...
} 
Azra, Azyumardi. Pendidikan Islam Tradisi dan Modernisasi Menuju Milenium Baru. Jakarta: Logos Wacana Ilmu, 2005.

). Paradigma Baru Pendidikan Nasional, Rekonstruksi dan Demokratisasi, Jakarta : Kompas, 2006.

Arsyil Rahman Putra, Andi. Kemukjizatan Al-Qur'an Tentang Teori Relativitas; https://idid.facebook.com/notes/andi-arsyil-rahman-putra/kemukjizatan

alquran tentang teori relativitas/10150670848708756/. Adapted and quoted on monday, 5 December 2016.

Bachtiar, Amsal. Filsafat Ilmu. Jakarta: Radjawali Press, 2005.

Burhanuddin, Jajat. Mencetak Muslim Modern. Jakarta: Raja Grafindo Persada, 2006.

Bugn, Burhan. Sosiologi Komunikasi. Bandung: PT. Remaja Rosda Karya, 2008.

Ciputra. Ciputra Quantum Leap 2 Kenapa \& Bagaimana ? Entrepreneurship Mengubah Masa Depan Bangsa dan Masa Depan Anda, Jakarta: Kompas Gramedia, 2011.

Daulay, Haidar Putra. Sejarah Pertumbuhan dan Pembaruan Pendidikan Islam di Indonesia, Jakarta: Kencana, 2009.

). Pemberdayaan Pendidikan Islam di Indonesia. Jakarta: Rineka Cipta, 2009.

Depdiknas. Kamus Besar Bahasa Indonesia. Jakarta: Balai Pustaka, 2008.

Departemen Agama. Rekonstruksi Sejarah Pendidikan Islam di Indonesia. Jakarta: Ditperta Islam, Ditjen Bagais, 2006.

Era Muslim, Media Islam Rujukan, Fakta-Fakta Ilmiah Al-Qur'an Terbukti, https://www.eramuslim.com/peradaban/quran-sunnah/fakta-fakta-ilmiah-al-quranterbukti.htm, adapted and quoted on tuesday, 6 December 2016.

Fajar, Malik. Reorientasi Pendidikan Islam. Jakarta: Fajar Dunia, 2005.

(___. Holistika Pemikiran Pendidikan. Jakarta: Raja Grafindo Persada, 2005.

Fatkurrohman, Dafit. Pemikiran dan Aksi Imam Suprayogo dalam Membangun Kerja Sama Kelembagaan. Thesis: Tarbiyah Universitas Islam Negeri (UIN) Malang Faculty, 2008

Fridiyanto, Manajemen Perubahan: Studi Kepemimpinan Prof. Dr. Imam Suprayogo UIN Malang; http://www.academia.edu/3136880/Manajemen_Perubahan_St udi_Kepemimpinan_Prof._Dr._Imam_Suprayogo_UIN_Malang, adapted and quoted on Wednesday, 23 Nopember 2016.

Hamami, Tasman. "Pendidikan Agama Islam di Sekolah Umum Sebagai Keharusan Sejarah,” In Journal of Islamic Education, Vol. 1, 2004

Handrianto, Budi. Islamisasi Sains Sebuah Upaya MengIslamkan Sains Barat Modern. Jakarta: Pustaka Al-Kautsar, 2010.

Hamdani, Konsep Integrasi pendidikan Islam Mohammad Natsir dan Implementasinya dalam pengembangan Kurikulum, Thesis: Tarbiyah and Teacher Training Faculty Universitas Islam Negeri Sunan Kalijaga Yogyakarta, 2015.

Jannah, Miftahul. Penafsiran Ulul Albab dalam Tafsir Al-Misbah, Thesis: Ushuluddin Faculty and Islamic Perspective Universitas Islam Negeri Sunan Kalijaga Yogyakarta, 2015

Kosim, Muhammad. Pemikiran Pendidikan Islam Ibnu Khaldun. Jakarta: Rineka Cipta, 2012.

Kartanegara, Mulyadhi. Integrasi Ilmu: Sebuah Rekonstruksi Holistik. Bandung: Arasy Mizan-UIN Jakarta Press, 2005.

Masruri, M. Hadi. Filsafat Sains dalam Al-Qur'an: Melacak Kerangka Dasar Integrasi Ilmu dan Agama. Malang: UIN-Malang Press, 2007. 
Mashudi. Reintegrasi Epistemologi Keilmuan Islam dan Sekuler, Thesis: Ushuluddin Faculty. Universitas Islam Negeri (UIN) Sunan Kalijaga Yogyakarta, 2008.

Majalah Hidayatullah, "Mengubah Univesitas Kelas "Teri" Jadi Berkualitas; http://majalah.hidayatullah.com/2011/10/mengubah-universitas-kelas-

$\% \mathrm{E} 2 \% 80 \% 9 \mathrm{Dteri} \% \mathrm{E} 2 \% 80 \% 9 \mathrm{D}$-jadi-berkualitas/, adapted and quoted monday, 4 April 2016.

Muhaimin. Wacana Pengembangan Pendidikan Islam. Surabaya: Pustaka Pelajar, 2003.

Murni. Wahid. Penguatan Kelembagaan Menuju Destinasi Utama Pendidikan Islam Global, Menyongsong World Class University. UIN Maliki Press, Third Edition, 2016. Adapted and quoted on monday, 28 Nopember 2016.

Munandar, Aries. Imam Suprayogo dalam Pendidikan Islam di Indonesia; adapted and quoted on Tuesday, 22 Nopember 2016.

Maimun, Agus. Madrasah Unggulan Lembaga Pendidikan Alternatif di Era Kompetitif, Malang: UIN Press, 2010.

Pranata, Dwi Chandra. "Komunikasi Persuasi Prof. DR. Imam Suprayogo", Thesis: Psychology of Maulana Malik Ibrahim Malang Faculty, 2016.

Prihatin, Eka. Elin Rosalin, Taufani, Cepi Triatna. Konsep Pendidikan. Bandung: Karsa Mandiri Persada, 2008.

Rosadis Astra, Andi. "Integrasi Ilmu Sosial dengan Teks Agama dalam Perspektif Tafsir AlQur'an", dalam Jurnal Keilmuan Tafsir Hadis, Vol. 4 No. 1, 2014.

Suprayogo, Imam. Paradigma Pengembangan Keilmuan Di Perguruan Tinggi. Malang: UIN Malang Press, 2012.

Suprayogo, Imam. Pemimpin itu Seperti Pengembala Kuda, Personal Website, intellectualadventure.com, Saturday 20 February 2016.

(__ Membangun Integrasi Ilmu dan Agama: Pengalaman UIN Malang; http://tulisanterkini.com/artikel/keislaman/umum/5382-membangun integrasi-ilmu-danagama pengalaman uin-maulana-malik-ibrahim malang.html, Adapted and quoted on Friday, 25 Nopember 2016.

(__ Universitas Islam Unggul (Memadukan Ilmu Umum dan Agama). Malang: UIN Malang Press, 2009.

(_ Keberhasilan Membangun Perguruan Tinggi Islam, http://www.imamsuprayogo.com/viewd_artikel.php?pg=57, Adapted and quoted on Saturday, 03 December 2016.

(___. Memperkokoh Budaya Akademik Perguruan Tinggi, http://www.imamsuprayogo.c om/viewd_artikel.php?pg=71, Adapted and quoted on Friday, 25 Nopember 2016.

(__ . Memaknai Akar Pohon Ilmu UIN Maliki Malang; Adapted and quoted on Monday 28 November 2016.

). Posisi Strategis Dosen di Perguruan Tinggi, http://www.imamsuprayogo.com/viewd_artikel.php?pg=102, Adapted and quoted on Sunday, 04 December 2016.

Sugiono, Metode Penelitian Pendidikan. Bandung: Alfabeta, 2010.

Setyosari, Punaji. Metode Penelitian Pendidikan dan Pengembangan. Jakarta: Raja Grafindo Persada, 2005.

Suryabrata, Sumadi. Metodologi Penelitian. Jakarta: Raja Grafindo Persada, 2005. 
Siswanto. "Perspektif Amin Abdullah tentang Integrasi-Interkoneksi dalam kajian Islam”. On Journal Tasawuf Pemikiran Islam, Vol. 3, No. 2. Adapted and quoted on Monday Senin 28 November 2016.

Suwendi. Sejarah dan Pemikiran Pendidikan Islam. Jakarta: Raja Grafindo Persada, 2003.

Zuhairini. Filsafat Pendidikan Islam. Jakarta: Bumi Aksara, 2004

Zainuddin, Muhammad In'am Esha (ed). Horizon Baru Pengembangan Pendidikan Islam. Malang: UIN Press, 2004

Zamroni. Pendidikan Islam Berorientasi Masa Depan; Konsep Pendidikan Ulul Albab Perspektif Imam Suprayogo”. On journal At-Turas, Vol. 1 No. 1, 2014, hal. 53. Adapted and quoted on Sunday, 27 Nopember 2016.

Zainiyati, Husniyatus Salamah. "Integrasi Pesantren kedalam Sistem Pendidikan Tinggi Agama Islam,” On Dissertation, Surabaya: PPs. IAIN Sunan Ampel Surabaya, 2012.

). Desain Kurikulum Integratif, on journal Pendikan Islam, Vol 8, No. 2, 2014.

). Model Kurikulum Integratif Pesantren Mahasiswa and UIN Maliki Malang," on journal Studi Keislaman, Vol. 18 No. 1, 2014. 